\section{Kjedelig og begrenset om rusavhengighet i Europa}

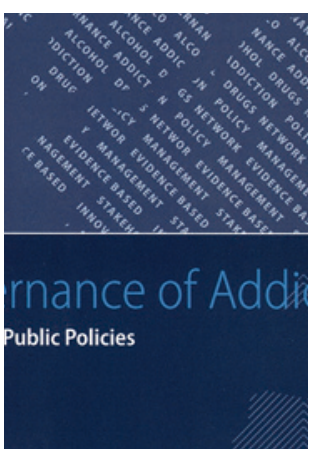

\author{
Tamyko Ysa, Joan Colom, \\ Adrià Albareda et al. \\ Governance of addictions \\ European public policies. 272 s, tab, ill \\ Oxford: Oxford University Press, 2014. \\ Pris GBP 32
}

ISBN 978-0-19-870330-3

Governance of addictions handler om hvordan ulike land forholder seg til alkohol, tobakk og narkotika og hva kan vi lære av hverandre. Dessverre er boken søvndyssende i formen og selvfølgelig i innholdet.

Bakgrunnen er et stort europeisk forskningsprosjekt (ALICE RAP) der man har sett på avhengighet $\mathrm{i}$ Europa fra ulike perspektiver. Etter en innledning og beskrivelse av hvilke kilder som brukes, får vi en oversikt over EUs rolle i arbeidet med avhengighet. Deretter følger fire kapitler som beskriver ulike tilnærminger i dagens Europa og et oppsummerende kapittel. Boken avsluttes med et appendiks på nesten hundre sider som lister opp fakta om ulike europeiske land. Målgruppen er personer som utformer politikk, og den har begrenset interesse for klinikere. Skrivestilen minner om en rapport.

Hovedbudskapet er at europeiske land kan deles inn i fire grupper: Trendsetterne som har en helhetlig struktur for både alkohol og narkotiske stoffer og en vektlegging av dekriminalisering og skadereduksjon, for eksempel Nederland, Spania og Italia. Deretter følger en gruppe land som har en noe strengere regulering. Norge er plassert i denne gruppen. Land som har en mindre helhetlig struktur, kalles «overgangsland» og inkluderer, merkelig nok, blant annet Danmark. Til sist kommer landene som har en tradisjonell tilnærming med sterk vektlegging av politi og straff.

Bakgrunnen for klassifiseringen er en lang rekke fakta om landene fra ulike undersøkelser, blant annet data fra OECD. Disse faktaene blir så redusert til en samleskår på to hoveddimensjoner: struktur og strategi. For eksempel vil land som har avkriminalisert narkotika og fokuserer på skadereduksjon, skåre høyt på noe som kalles «relational management of well-being». Dette er i den ene enden av strategiskalaen. Den motsatte strategien sies å være en som er rettet mot å beskytte individer, eksemplifisert ved at innenriksministeriet og ikke helseministeriet, har hovedansvaret for området. Tilsvarende bruker man ulike indikatorer til å avgjøre om et land har en helhetlig struktur i sin tilnærming. Land som har lignende verdi på samleindeksene for strategi og struktur blir så klassifisert i samme gruppe.

Forfatterne begrenser seg til å klassifisere land, noe som vil skuffe de som leter etter mer beslutningsrelevant kunnskap om hva slags effekter de ulike systemene har.

Hans Olav Melberg

Førsteamanuensis, Avdeling for helseledelse og helseøkonomi

Universitetet i Oslo

\section{For alle med nevroradiologisk interesse}

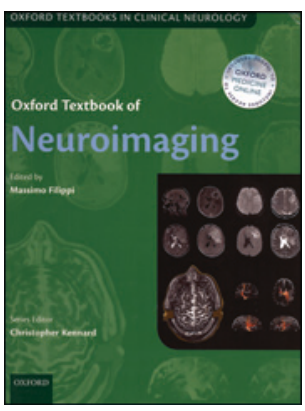

Massimo Filippi, red. Oxford textbook of neuroimaging

414 s, tab, ill. Oxford: Oxford University Press, 2015. Pris GBP 125 ISBN 978-0-19-966409-2

Nevroradiologien har gjennom utvikling av CT og MR fått en betydelig økt spesifisitet og diagnostisk verdi de siste tiårene. I tillegg har metoder som ultralyd, positronemisjonstomografi (PET) og enfotonstomografi (SPECT) ført til at diagnostikken spenner over et enormt teknisk spekter med stor nytteverdi for pasient og lege. Selv om spesialitetene fortsatt har ganske klare avgrensninger, er vi kommet nærmere et felles felt som mange ønsker å benevne nevrovitenskap.

Denne boken gir basale, tekniske forklaringer av de enkelte metodene. Kjøp av boken gir direkte tilgang til Oxford Medicine Online for ett år, en fantastisk mulighet til å suge mer lærdom ut av forfattere og referanser. Målgruppen er først og fremst nevrologer og nevroradiologer, men også studenter i nevrofagene.

For radiologene bidrar dette til oversikt over hvilke differensialdiagnoser man kan overveie, men også hvilke metoder som best kan gi klinikeren de svar han ønsker. Dette er problemstillinger man tidligere diskuterte og løste under røntgendemonstrasjonene, men dagens klinikere arbeider ofte med større tidspress og uten enkelt å kunne konsultere et kollegium.

Massimo Filippi er kjent for sitt store engasjement for multippel sklerose, men han har også et stort nettverk til å bygge en lærebok av denne typen. Forfatterlisten er stor, med bidragsytere fra Sverige og Danmark, men dessverre ingen fra Norge, selv om det er norske referanser.

Boken er delt i to hoveddeler over 32 kapitler: metoder og kliniske applikasjoner. Datamengden er stor og overveielsene gode, selv om fremstillingen av metodene dels kan være vanskelig å følge, og ytterligere forenklinger kunne gjort fremstillingen lettere. Det er mange gode illustrasjoner, men noen er dårlige - for eksempel er noen av MR-bildene litt mørke.

Jeg savner også en bedre gjennomgang av CT og MR angiografi selv om disse metodene er meget godt kjent på forhånd. Mer bruk av illustrasjoner, tabeller og oppsummeringer kunne gjort det hele mer lettlest og stimulerende. Her har vi fortsatt en vei å gå i europeisk litteratur sammenlignet med amerikanske lærebøker som Anne Osborns store læreverk om nevroradiologi.

La ikke dette ta bort interessen for Filippis bok, som er interessant for nyutdannede kolleger og studenter, men også for etablerte nevrologer og nevroradiologer. Den er til oppdatering, råd og ettertanke. Vi bør se boken i de fleste nevrologiske og nevroradiologiske bokhyller.

\section{Søren Jacob Bakke}

Tidligere overlege, Nevroradiologisk seksjon

Oslo universitetssykehus, Rikshospitalet 